\title{
EFFECT OF FINANCING TO DEPOSIT RATIO AND NON- PERFORMING FINANCING OF RETURN ON ASSETS WITH A CAPITAL ADEQUACY RATIO AS VARIABLE INTERVENING IN ISLAMIC BANKING IN INDONESIA IN 2012-2019
}

\author{
Lutfia Abriet Fajriati $^{1}$, Asmak Ab Rahman², Shinta Maharani ${ }^{3}$ \\ 1,3 The State of Islamic Studies Ponorogo, Indonesia \\ ${ }^{2}$ Department of Sharia and Economics, Academy of Islamic Studies, University of \\ Malaya, Malaysia \\ Email: dhodhotalvian04@gmail.com¹, asmak@um.edu.my², \\ maharani@iainponorogo.ac.id ${ }^{3}$
}

\begin{abstract}
Income in Islamic banks is primarily determined by how much profit or profit the bank receives. Several factors that become indicators of Islamic Bank income are financing funding and the lack of non-performing financing. The greater the financing of third-party funds, the greater the profit to be received, and the higher the NPF level, the lower the bank's profit. Banks with a large enough CAR will be able to increase bank profitability. The NPF variable harms ROA because a decrease in the NPF ratio will increase bank profits. And the CAR variable as an intervening variable also has a positive effect on ROA because an increased CAR will increase bank profitability. Whereas when the NPF decreases, the profitability of Islamic banks also decreases, while when FDR and CAR increase, ROA decreases. The formulation of the problem in this study is whether there is a partial and simultaneous influence of FDR and NPF on ROA?. Is there a partial and simultaneous influence of FDR, NPF, and CAR on ROA. This research is a quantitative study with the population of Islamic Commercial Banks in Indonesia registered with the Financial Services Authority (OJK). In comparison, the sample of this study was determined by purposive sampling method with criteria determined by the researcher so that 4 Islamic commercial banks were obtained from 2012 to 2019. This study used secondary data with research methods using quantitative methods with an associative approach. Data collection techniques were carried out by observation. The data analysis technique used in this research is the associative analysis technique, namely multiple linear regression testing, classical assumption test, hypothesis testing, coefficient of determination test, and path analysis. The results of this study indicate that partially the FDR variable has an insignificant negative effect on ROA, NPF has a significant negative effect on ROA. In comparison, CAR has a positive and significant effect on ROA. Simultaneously, the FDR and NPF variables have no significant effect on ROA. For the results of the path analysis, it is found that the CAR variable cannot mediate the effect of FDR and NPF on ROA.
\end{abstract}

Keywords: Return on Asset, Non Performing Financing, Financing to Deposit Ratio, Intervening

\section{INTRODUCTION}

The bank has a function as a distributor of funds. Or in other words, banks provide financing to customers(Ismail, 2016, p. 25). Self-financing according to article 1 point 12 of Law no. 10 of 1998 jo. UU no. 7 of 1992 concerning banking is the provision of 
money or an equivalent claim based on an agreement or agreement between the bank and another party that requires the party being financed to return the money or claim after a certain period with compensation or profit-sharing.

Table 1. The development of Return On Assets, Financing to Deposits Ratio, NonPerforming Financing, and Capital Adequacy Ratio from 2012-2019 PT. Victoria Sharia Bank

\begin{tabular}{|c|c|c|c|c|}
\hline Year & FDR $(\%)$ & NPF $(\%)$ & CAR (\%) & ROA (\%) \\
\hline 2012 & 73.78 & 2.41 & 28.08 & 1.43 \\
\hline 2013 & 84.65 & 3.31 & 18,40 & 0.50 \\
\hline 2014 & 95.19 & 4.75 & $15.27 \uparrow$ & $-1.87 \downarrow \downarrow$ \\
\hline 2015 & 95.29 & 4.82 & $16.14 \uparrow$ & $-2.36 \downarrow \downarrow$ \\
\hline 2016 & 100.66 & 4.35 & $15.98 \downarrow$ & $-2.19 \uparrow \uparrow$ \\
\hline 2017 & 83.53 & $4.08 \downarrow$ & 19.35 & $0.36 \uparrow \downarrow$ \\
\hline 2018 & 82.78 & $3.46 \downarrow$ & $22.07 \uparrow$ & $0.32 \downarrow \downarrow$ \\
\hline 2019 & 80.52 & $2.64 \downarrow$ & 19.44 & $0.05 \downarrow$ \\
\hline
\end{tabular}

Table 2. The development of Total Return On Assets, Financing to Deposits Ratio, Non-Performing Financing, and Capital Adequacy Ratio from 2012-2019 at PT. Bank BRI Syariah

\begin{tabular}{ccccc}
\hline Year & FDR (\%) & NPF (\%) & CAR (\%) & ROA (\%) \\
\hline 2012 & 103.07 & 1.84 & 1.35 & 1.19 \\
\hline 2013 & 102.70 & 3.26 & $14.49 \uparrow$ & $1.15 \downarrow$ \\
\hline 2014 & 93.90 & 3.65 & 12.89 & 0.08 \\
\hline 2015 & 84.16 & $3.89 \uparrow$ & 13.94 & $0.77 \uparrow \uparrow$ \\
\hline 2016 & 81.42 & 3.19 & 20.63 & 0.95 \\
\hline 2017 & 71.87 & 4.75 & 20.05 & 0.51 \\
\hline 2018 & 75.49 & 4.97 & $29.73 \uparrow$ & $0.43 \downarrow \downarrow$ \\
\hline 2019 & 80.12 & $3.38 \downarrow$ & 25.26 & $0.31 \downarrow \downarrow$ \\
\hline
\end{tabular}

Source: www.brisyariah.co.id

Based on data on the development of financial statements from PT. The BRI Syariah Bank can be seen that in 2014 to 2015, the FDR ratio decreased and ROA increased, and from 2015 to 2016, the ROA ratio increased, and the FDR ratio decreased, and in 2017 to 2018, the ROA ratio decreased, and the FDR ratio decreased. It was increased in that year. Then in 2014 to 2015, the NPF ratio increased, but the ROA also increased, and in 2018 to 2019, the ROA ratio decreased, and the NPF ratio also decreased. And in 2012 to 2013, the CAR ratio increased, but ROA decreased, and in 2017 to 2018, the ROA ratio decreased, but the CAR ratio increased that year. 
Table 3 The development of Total Return On Assets, Financing to Deposits Ratio, Non-Performing Financing, and Capital Adequacy Ratio from 2012-2019 at PT. Bank Muamalat Indonesia

\begin{tabular}{lllll}
\hline Year & FDR $(\%)$ & NPF $(\%)$ & CAR $(\%)$ & ROA $(\%)$ \\
\hline 2012 & 94.15 & 1.81 & 11.57 & 1.54 \\
\hline 2013 & 99.99 & $1.56 \downarrow$ & $14.05 \uparrow$ & $0.50 \downarrow \downarrow \downarrow$ \\
\hline 2014 & 84.14 & 4.85 & $14.15 \uparrow$ & $0.17 \downarrow$ \\
\hline 2015 & 90.3 & $4.20 \downarrow$ & 12 & $0.13 \downarrow \downarrow$ \\
\hline 2016 & 95.13 & 1.4 & 12.74 & 0.14 \\
\hline 2017 & 84.41 & 2.75 & $13.62 \uparrow$ & $0.04 \downarrow$ \\
\hline 2018 & 73.18 & 2.58 & $12.34 \downarrow$ & $0.08 \uparrow \uparrow$ \\
\hline 2019 & 73.51 & 4.3 & $12.42 \uparrow$ & $0.05 \downarrow \downarrow$ \\
\hline
\end{tabular}

Source: www.bankmuamala t.co.id

Table 4 The development of Total Return On Assets, Financing to Deposits Ratio, Non-Performing Financing, and Capital Adequacy Ratio from 2012-2019 at PT. Panin Dubai Sharia Bank

\begin{tabular}{lllll}
\hline Year & FDR (\%) & NPF $(\%)$ & CAR $(\%)$ & ROA (\%) \\
\hline 2012 & 105.66 & 0.19 & 32,20 & 3.48 \\
\hline 2013 & 90,40 & 0.77 & 20.83 & 1.03 \\
\hline 2014 & 94.04 & 0.29 & 25.69 & 1.99 \\
\hline 2015 & 96.43 & 1.94 & 20,30 & 1.14 \\
\hline 2016 & 91.99 & $1.86 \downarrow$ & $18.17 \downarrow$ & $0.37 \downarrow \uparrow$ \\
\hline 2017 & 86.95 & 4.83 & 11.51 & -10.77 \\
\hline 2018 & 88.82 & 3.84 & 23.15 & 0.26 \\
\hline 2019 & 96.23 & $2.80 \downarrow$ & 14.46 & $0.25 \downarrow \downarrow$ \\
\hline
\end{tabular}

Source: www.paninbanksya riah.co.id

Based on data on the development of financial statements from PT. Bank Muamalat Indonesia, from 2012 to 2013, the FDR ratio increased, and ROA decreased; from 2014 to 2015, the FDR ratio increased, and ROA decreased. And in 2017 to 2018, the ROA ratio increased, but the FDR ratio decreased, and in the following year, 2018 to 2019, the FDR ratio increased, but the ROA ratio decreased. Then in 2012 to 2015, the NPF ratio decreased, and in fact, ROA decreased as well, and from 2015 to 2016, the ROA ratio increased, but the NPF ratio decreased. Then in 2012 to 2014, the CAR ratio increased, but ROA decreased, and in 2016 to 2017, the ROA ratio decreased, and the CAR ratio increased, in 2017 to 2018, the ROA ratio increased, but the CAR ratio decreased, and in 2018 to 2019, the ROA ratio decreased but instead, the CAR ratio increased that year. 


\section{LITERATURE REVIEW}

Return on Assets is part of the profitability ratio or profitability ratio that can measure the level of effectiveness of management performance. Good performance will be shown through the success of management in generating maximum profit for the company. Measurement of profitability ratios can be done by comparing the various components in the income statement or balance sheet. Measurements can be made for several periods. The aim is to monitor and evaluate the level of development of the company's profitability from time to time(Syamsuddin, 1998, p. 92).

One measure of profitability ratio analysis can use the Return On Asset (ROA) ratio. Return On Assets (ROA) is essential for banks because Return On Assets (ROA) is used to measure the effectiveness of the company in generating profits by utilizing its assets. The greater the ROA owned by a company in generating profits by utilizing its assets. The greater the ROA owned by a company, the efficient use of assets will increase profits. Significant profits will attract investors because the company has a higher rate of return(Umam, 2013, pp. 345-346). Return on Assets (ROA) was chosen as an indicator for measuring banking financial performance.

\section{RESEARCH METHODS}

The variables used in this study consisted of 2 independent variables, one dependent variable, and one intervening variable. This study's independent variable serves as a determinant of direction or provides specific changes to the dependent variable. The independent variables in this study are Financing to Deposits Ratio (FDR) as variable $\mathrm{X}_{1}$ and Non-Performing Financing (NPF) as variable $\mathrm{X}_{2}$. This research was conducted on the annual financial statements of Islamic Commercial Banks for a period of 8 years (Annual reports from 2012-2019). The criteria used to determine the sample in this study are as follows:

1. Sharia Commercial Banks registered with the Financial Services Authority (OJK) for the period 2012-2019.

2. Islamic Commercial Banks publish complete financial reports for the period 20122019.

3. The financial reports provided are annual financial reports for the period 2012-2019 published on the websites of each of these Islamic Banks. 
4. Islamic Commercial Banks in Indonesia that have complete data needed regarding the measurement of profitability variables, Financing to Deposits Ratio (FDR), Non-Performing Financing (NPF), and Capital Adequacy Ratio (CAR) for the period 2012-2019.

Based on this purposive sampling method(Sugiono, 2018), it was noted that there were four samples used in this study. The Islamic commercial banks that were sampled in this study are listed in the following table:

1. PT. Panin Dubai Sharia Bank

2. PT. Bank Muamalat Indonesia

3. PT. BRI Syariah Bank

4. PT. Victoria Sharia Bank

The criteria are Islamic banks that have published complete financial reports in 20122019.

\section{RESULTS AND DISCUSSION}

\section{Data statistics are used to describe generalizations}

Descriptive statistics provide an overview of the research object that is sampled in the research conducted. By explaining descriptive statistics, it is hoped that it can provide an initial description of the problems studied in the study. This descriptive test describes the variables of Financing To Deposit Ratio (FDR), Non-Performing Financing (NPF), Capital Adequacy Ratio (CAR), and Return On Assets (ROA).

Table 5 Descriptive Statistics

\begin{tabular}{llcccc}
\hline & $\mathbf{N}$ & Minimum & Maximum & mean & Std. Deviation \\
\hline FDR & 32 & 71.87 & 105.66 & 88.5769 & 9.48954 \\
\hline NPF & 32 & 0.19 & 4.97 & 3.0850 & 1.38240 \\
\hline ROA & 32 & -10.77 & 3.48 & 0.0634 & 2.26070 \\
\hline CAR & 32 & 1.35 & 32.20 & 17.5709 & 6,31935 \\
\hline
\end{tabular}

Source: Secondary Data processed 2021.

\section{Simple Linear Regression Analysis Results}

Based on the table 6, the following simple linear regression equation is obtained:

$$
Y=31.591+(-0.158 X)
$$

Based on the simple linear regression equation above, it is known:

1) The constant value is 31.591 , meaning that if the FDR value is 0 , the CAR value is 31.591 . 
2) The regression coefficient value of the FDR is -0.158 , which is negative, meaning that if the FDR is increased by 1 unit, the CAR will decrease by 0.158 .

Table 6. The linear regression analysis of the FDR. Variable

\begin{tabular}{llccccc}
\hline \multirow{2}{*}{ Model } & \multicolumn{2}{c}{$\begin{array}{c}\text { Unstandardized } \\
\text { Coef }\end{array}$} & \multicolumn{2}{l}{$\begin{array}{l}\text { Standardized } \\
\text { Coef }\end{array}$} & \multirow{2}{*}{ t } & \multirow{2}{*}{ Sig. } \\
\cline { 2 - 5 } & B & SE & Beta & & \\
\hline 1 & (Constant) & 31.591 & 10.519 & & 3.003 & 0.005 \\
\hline & FDR & -0.158 & 0.118 & -0.238 & -1.340 & 0.190 \\
\hline
\end{tabular}

Dependent Variable: CAR

Table 7. The linear regression analysis of the NPF variable

\begin{tabular}{llccccc}
\hline \multirow{2}{*}{ Model } & \multicolumn{2}{c}{$\begin{array}{c}\text { Unstandardized } \\
\text { Coefficients }\end{array}$} & $\begin{array}{c}\text { Standardized } \\
\text { Coefficients }\end{array}$ & \multirow{2}{*}{ t } & \multirow{2}{*}{ Sig. } \\
\cline { 3 - 5 } & B & SE & Beta & & \\
\hline 1 & (Constant) & 19.872 & 2.776 & & 7.158 & 0.000 \\
\hline & NPF & -0.746 & 0.823 & -0.163 & -0.906 & 0.372 \\
\hline
\end{tabular}

Dependent Variable: CAR

Table 8. The test results of simple linear regression analysis of the FDR. Variable

\begin{tabular}{llccccc}
\hline \multirow{2}{*}{ Model } & \multicolumn{2}{c}{$\begin{array}{c}\text { Unstandardized } \\
\text { Coefficients }\end{array}$} & $\begin{array}{c}\text { Standardized } \\
\text { Coefficients }\end{array}$ & & \multirow{2}{*}{ Sig. } \\
\cline { 3 - 6 } & B & SE & Beta & & \\
\hline 1 & (Constant) & -1.190 & 3.867 & & -0.308 & 0.760 \\
\hline & FDR & 0.014 & 0.043 & 0.059 & 0.326 & 0.747 \\
\hline
\end{tabular}

a. Dependent Variable: ROA

Table 9. The test results of simple linear regression analysis of the NPF. Variable

\begin{tabular}{llccccc}
\hline \multirow{2}{*}{ Model } & \multicolumn{2}{c}{$\begin{array}{c}\text { Unstandardized } \\
\text { Coefficients }\end{array}$} & $\begin{array}{c}\text { Standardized } \\
\text { Coefficients }\end{array}$ & \multirow{2}{*}{ S } & \multirow{2}{*}{ Sig. } \\
\cline { 3 - 6 } & & B & SE & Beta & & \\
\hline 1 & (Constant) & 2.672 & 0.862 & & 3.101 & 0.004 \\
\hline & NPF & -0.846 & 0.256 & -0.517 & -3.309 & 0.002 \\
\hline
\end{tabular}

a. Dependent Variable: ROA

Table 10. The test results of simple linear regression analysis of the CAR. variable

\begin{tabular}{llccccc}
\hline \multirow{2}{*}{ Model } & \multicolumn{2}{c}{$\begin{array}{c}\text { Unstandardized } \\
\text { Coefficients }\end{array}$} & $\begin{array}{c}\text { Standardized } \\
\text { Coefficients }\end{array}$ & & \multirow{2}{*}{ Sig. } \\
\cline { 2 - 5 } & B & SE & Beta & & \\
\hline 1 & (Constant) & -1.930 & 1.155 & & -1.671 & 0.105 \\
\hline \multicolumn{2}{c}{ CAR } & 0.113 & 0.062 & 0.317 & 1.831 & 0.077 \\
\hline
\end{tabular}

a. Dependent Variable: ROA 
Based on the table 7, the following simple linear regression equation is obtained:

$$
Y=19.872+(-0.746 X)
$$

Based on the simple linear regression equation above, it is known:

1) The constant value is 19.872 , meaning that if the NPF value is 0 then the CAR value is 19.872 .

2) The regression coefficient value of the NPF is -0.746 , which is negative, meaning that if the NPF is increased by 1 unit, the CAR will decrease by 0.746 .

Based on the table 8 , the following simple linear regression equation is obtained:

$$
Y=-1.190+\mathbf{0 . 0 1 4 X}
$$

Based on the simple linear regression equation above, it is known:

1) The constant value is -1.190 , meaning that if the FDR value is 0 , the ROA value is 1.190 .

2) The regression coefficient value of the FDR is 0.014 , which is positive, meaning that if the FDR is increased by 1 unit, the ROA will also increase by 0.014 .

3) Constant (a): -1.190 , the constant value is negative, meaning that if the FDR variable score is considered non-existent or equal to zero, the ROA score will decrease. bX coefficient: 0.014 , the coefficient of the FDR variable is positive, meaning that the effect of FDR on ROA is positive and quite strong. If the FDR score increases, the ROA will be higher.

Based on the table 9, the following simple linear regression equation is obtained:

$$
Y=2.672+(-0.846 X)
$$

Based on the simple linear regression equation above, it is known:

1) The constant value is 2.672 , meaning that if the NPF value is 0 , then the ROA value is 2.672 .

2) The regression coefficient value of the NPF is -0.846 , which is negative, meaning that if the NPF is increased by 1 unit, the ROA will decrease by 0.846 .

Based on the table 10, the following simple linear regression equation is obtained:

$$
Y=-1.930+\mathbf{0 . 1 1 3 X}
$$

Based on the simple linear regression equation above, it is known: 
1) The constant value is -1.930 , meaning that if the CAR value is 0 , the ROA value is 1.930 .

2) The regression coefficient value of the CAR is 0.113 , which is positive, meaning that if the CAR is increased by 1 unit, the ROA will also increase by 0.113 .

3) Constant (a): -1.930 , the constant value is negative, meaning that if the CAR variable score is considered non-existent or equal to zero, then the ROA score will decrease.

4) bX coefficient: 0.113 , the coefficient of the CAR variable is positive, meaning that the effect of CAR is positive and quite strong. If the CAR score increases, the ROA will be higher.

\section{Multiple Linear Regression Analysis Results}

Multiple linear regression is often used to solve regression analysis problems involving the relationship of two or more independent variables. ${ }^{18}$ In this study, regression analysis was used to determine two equations. The first equation is the effect of FDR and NPF, against CARs. The second equation, namely, the effect of FDR, NPF, and CAR, on ROA.

Table 11. Multaiple linear regression analysis test results Equation 1

\begin{tabular}{lccccc}
\hline \multirow{2}{*}{ Model } & \multicolumn{2}{l}{$\begin{array}{l}\text { Unstandardized } \\
\text { Coefficients }\end{array}$} & $\begin{array}{l}\text { Standardized } \\
\text { Coefficients }\end{array}$ & t & Sig. \\
\cline { 2 - 5 } & $\mathbf{B}$ & SE & Beta & & \\
\hline (Constant) & 43.509 & 12.514 & & 3.477 & 0.002 \\
\hline FDR & -0.243 & 0.126 & -0.365 & -1.933 & 0.063 \\
\hline NPF & -1.427 & 0.863 & -0.312 & -1.653 & 0.109 \\
\hline
\end{tabular}

Dependent Variable: CAR

Based on the table 11, the following multiple linear regression equation is obtained:

$$
\mathrm{Z}=43.509+\left(-0.243 \mathrm{X}_{1}\right)+\left(-1.427 \mathrm{X}_{2}\right)
$$

Based on table 11 above, it can be concluded that:

1) The constant is 43.509 without being influenced by other variables. The CAR is 43.509 . 
2) The FDR regression coefficient is -0.243 , meaning that if the FDR variable is increased by 1 unit, the CAR will decrease by 0.243 , assuming other variables remain.

3) The NPF regression coefficient is -1.427 , meaning that if the NPF is increased by 1 unit, the CAR will decrease by 1.427 , assuming other variables remain.

Table 12. Multiple Linear Regression Test Results Equation 2

\begin{tabular}{lccccc}
\hline \multirow{2}{*}{ Model } & \multicolumn{2}{c}{$\begin{array}{c}\text { Unstandardized } \\
\text { Coefficients }\end{array}$} & $\begin{array}{c}\text { Standardized } \\
\text { Coefficients }\end{array}$ & \multirow{2}{*}{ t } & Sig. \\
\cline { 2 - 4 } & $\mathbf{B}$ & SE & Beta & & \\
\hline (Constant) & 3.684 & 4.775 & & 0.772 & 0.447 \\
\hline FDR & 0.025 & 0.043 & -0.107 & -0.594 & 0.557 \\
\hline NPF & -0.862 & 0.290 & -0.527 & -2.977 & 0.006 \\
\hline CAR & 0.074 & 0.06 & 0.206 & 1.236 & 0.227 \\
\hline
\end{tabular}

Dependent Variable: ROA

Based on the table 12, the following multiple linear regression equation is obtained:

$$
\mathrm{Y}=3.684+(-0.025) \mathrm{X}_{1}+(-0.862) \mathrm{X}_{2}+\mathbf{0 . 0 7 4} \mathrm{Z}
$$

Based on the table 12, it can be concluded that:

1) Constant of 3.684 without being influenced by other variables ROA of 3.684 .

2) The FDR regression coefficient is -0.025 , meaning that if the FDR variable is increased by 1 unit, the ROA will decrease by 0.025 , assuming other variables remain.

3) The NPF regression coefficient is -0.862 , meaning that if the NPF is increased by 1 unit, the ROA will decrease by 0.862 , assuming other variables remain

4) The CAR regression coefficient is -0.074 , meaning that if the CAR is increased by 1 unit, the ROA will also increase by 0.074 , assuming other variables remain.

Based on table 12 above, the regression coefficient value determines whether CAR can mediate FDR against ROA by multiplying the coefficient value between FDR against CAR with the coefficient value for CAR against ROA, and the result of multiplying the coefficient is compared with the coefficient value of FDR against ROA.

1) FDR regression coefficient on ROA is -0.107

2) FDR regression coefficient on CAR is -0.365 
3) The CAR regression coefficient on ROA is 0.206

4) The result of the multiplication of the indirect effect of the variable $X_{1}$ on $Y$ through Z $(-0.365) \times 0.206=-0.075$

Table 13. Path Analysis Test Results

\begin{tabular}{lccc}
\hline Variable & \multicolumn{2}{c}{ Contribution } \\
\cline { 2 - 4 } & Direct & No Direct & Total \\
\hline$X_{1}$ against $Z$ & -0.107 & & -0.107 \\
\hline$X_{2}$ against $Z$ & -0.527 & -0.527 \\
\hline$Z_{\text {against }} Y$ & 0.206 & 0.206 \\
\hline$X_{1}$ against $Y$ & -0.365 & -0.365 \\
\hline$X_{2}$ against $Y$ & -0.312 & -0.312 \\
\hline$X_{1}$ against $Y$ Via $Z$ & & $-0.365 X 0.206=-0.075$ & $-0.365 X 0.206=-0.075$ \\
\hline$X_{2}$ against $Z$ Via $Z$ & & $-0.312 X 0.206=-0.064$ & $-0.312 X 0.206=-0.064$ \\
\hline
\end{tabular}

Source: Secondary Data processed 2021.

The calculation of the direct and indirect effects of FDR and CAR as intermediary variables on Return On Assets shows a calculation that leads to a higher direct influence between X1 on Y. Where FDR is better to use a direct effect of -0.107 on Return On Assets while the indirect effect is - 0.075 through the intermediary Capital Adequacy Ratio, it means that FDR will increase. Return On Assets (ROA) without going through an intermediary factor Capital Adequacy Ratio (CAR) or using direct influence. The regression coefficient value determines whether CAR can mediate NPF against ROA by multiplying the coefficient value between NPF against CAR with the coefficient value for CAR against ROA and multiplying the coefficient value is compared with the coefficient value of NPF against ROA. The results are as follows:

1) NPF regression coefficient on ROA is -0.527

2) The regression coefficient of NPF to CAR is -0.312

3) The CAR regression coefficient on ROA is 0.206

4) The result of the multiplication of the indirect effect of the variable $X_{2}$ on $Y$ through Z $(-0.312) \times 0.206=0.064$

Based on the calculation of the direct and indirect effect of Non-Performing Financing (NPF) and Capital Adequacy Ratio (CAR) as an intermediary variable on return on assets (ROA) shows a calculation that leads to a higher direct influence between X2 on Y. Where is Non-Performing Financing (NPF)? Is it better to use a direct effect of -0.312 on return on assets (ROA) while the indirect effect of -0.064 ? It 
means that Non-Performing Financing (NPF) will increase return on assets (ROA) without going through the intermediary factor of Capital Adequacy Ratio (CAR) or using direct influence.

\section{The Effect of FDR on CAR in Islamic Commercial Banks}

The results showed that the FDR variable did not have a positive effect on CAR. Based on the partial test ( $\mathrm{t}$-test), the result of $\mathrm{t}$ count is $-1.933<$ from $\mathrm{t}_{\text {table }} \mathrm{l}=2.045$, so Ha is rejected. It means that FDR has no significant effect on CAR. Coefficient Financing To Deposit Ratio (FDR) is negative. This value can be interpreted that FDR does not have a positive effect on CAR. It is known that the sig value for FDR is 0.063 $>0.05$, meaning that FDR has no significant effect on CAR. The results of this study indicate that FDR has no significant effect on CAR. Not in line here shows that the Financing to Deposit Ratio level does not significantly impact the minimum capital adequacy that banks must meet. The high and low Financing to Deposit Ratio against the Capital Adequacy Ratio, which does not have an impact on the level of capital adequacy, occurs because of the limitation from Bank Indonesia that banks may channel financing above third party funds collected by the bank as long as it does not exceed $110 \%$.

\section{The Effect of NPF on CAR in Islamic Commercial Banks}

The results showed that the NPF variable did not have a positive effect on CAR. Based on the partial test ( $t$-test), the results of the $t$ count are $-1.653<$ from $t$ table $=2.045$, so $\mathrm{Ha}$ is rejected. It means that there is no effect of NPF on CAR. The NPF coefficient is 1.653, which is negative. This value can be interpreted that NPF does not have a positive effect on CAR. It is known that the sig value for NPF is $0.109>0.05$, meaning that NPF has no significant effect on CAR. From the data research carried out, the results obtained that Non-Performing Financing has a positive and insignificant effect on the Capital Adequacy Ratio of Islamic Commercial Banks. The positive relationship in the results of this study means that the smaller the potential for a bank's NPF will increase the amount of capital adequacy of the bank itself. Non-Performing financing is a financing condition where there is a deviation or deviation from the agreed terms of lending in the repayment of the financing so that there is a delay, legal action is required, or it is suspected. There is a possibility of a potential loss. ${ }^{21}$ The results 
showed that NPF had no significant effect on CAR. Not significant means indicating that the level of Non-Performing Financing does not significantly influence the Capital Adequacy Ratio. Non-performing financing can reduce income, or the bank may lose income from financing. The reduced income from this financing causes banks to have to use existing capital to finance their operations. Non-performing financing that often occurs can result in losses for banks because banks must use their capital to cover the capital that has been used to finance operational activities so that the capital adequacy ratio will also decrease. The results of this study are in line with research conducted by Fitria Permata Sandhi, ${ }^{22}$, which shows that Non-Performing Financing has a positive and insignificant effect on the Capital Adequacy Ratio.

\section{The Effect of FDR and NPF Together on CAR in Islamic Commercial Banks}

The results showed that the FDR and NPF variables together did not affect CAR. Based on the simultaneous test $(\mathrm{f})$, the calculated $\mathrm{F}$ value is $2.316<$ from the $\mathrm{F}$ table $=$ 3.316, so Ha is accepted. It means that the regression model obtained is not appropriate. So that the FDR and NPF variables together do not affect CAR. It is known that the significance value is $0.117>0.05$ so that the FDR (X1) and NPF (X2) variables together do not affect the CAR $(\mathrm{Z})$ variable. It is not under the theory that says that the bank's profit also increases when FDR increases.

\section{The Effect of FDR on ROA in Islamic Commercial Banks}

The results showed that the FDR variable harmed ROA. Based on the partial test (t-test), the results of the $\mathrm{t}_{\text {count are }}-0.594<$ from $\mathrm{t}_{\text {table }}=2.048$, so that $\mathrm{H} 04$ is accepted. It means that there is no influence between FDR on ROA. The FDR coefficient is -0.594, which is adverse to ROA. It is known that the significance value for FDR is $0.557>$ 0.05, meaning that FDR has no significant effect on ROA. According to Kasmir, the Financing Deposit Ratio (FDR) is a ratio to measure the composition of the amount of financing provided compared to the number of public funds and own capital used. Muhammad said that the financing to deposit ratio (FDR) is used as an indicator to determine the level of vulnerability. Rita Septiani and Putu Vivi Lestari said that the higher the value of the financing to deposit ratio (FDR), the better a bank is because it shows that the financing provided by banks is diverse so that it generates high profits and can be balanced with the capital owned by a bank. The results of this study are in 
line with Lilik Sriwahyuni's research. It is known that the FDR variable has no significant effect and denies the return on assets (ROA) with a significance value of $0.577>0.05$, so it can be concluded accept Ho, which means FDR has no significant effect and denies the return on assets. (ROA) with a coefficient value of 0.126 indicates a positive direction. This test shows that the FDR value does not affect the profitability of BRI Syariah banks. In this case, the increase in ROA of BRI Syariah banks is not influenced by the variable financing to deposit ratio (FDR). ${ }^{23}$

\section{The Effect of NPF on ROA in Islamic Commercial Banks}

The results showed that NPF did not have a positive effect on ROA. Based on the partial test ( $t$-test) obtained, the results of $t$ count of-2,977 $>$ from $t$ table $=2,048$, so Ha is accepted. It means that there is an influence between NPF on ROA. It is known that the significance value for NPF is $0.006<0.05$, meaning that NPF has a significant effect on ROA. So it can be concluded that NPF has a significant effect on ROA. This study shows significant results from the effect of Non-Performing Financing on profitability projected by Return On Assets, which means that Non-Performing Financing has a significant influence on the income earned to increase the amount of profit for the bank. In terms of its productivity ( performance), the problematic financing concerning the ability to generate income for the bank has decreased/decreased and may no longer exist. ${ }^{24}$ The impact that can be generated from the high value of Non-Performing Financing is the reduced opportunity to earn income from the distribution of funds to affect profit gains which will also impact the level of profitability of Islamic banks. The higher the level of Non-Performing Financing, the lower the level of profitability, and vice versa. If the Non-Performing Financing is low, it will increase the profitability of the bank. The results of this study are in line with research conducted by Syamsurizal Twenty-five of the research conducted shows that Non-Performing Financing (NPF) has a significant effect on Return On Assets (ROA).

\section{The Effect of CAR on ROA in Islamic Commercial Banks}

The results showed that CAR had a positive effect on ROA. Based on the partial test ( $\mathrm{t}$-test), the result of $\mathrm{t}$ count is $1.236<$ from $\mathrm{t}$ table $=2.048$, so Ha is rejected. It means that there is no effect of CAR on ROA. It is known that the significance value for CAR is $0.227>0.05$, meaning that CAR has no significant positive effect on ROA. So it can 
be concluded that CAR has no negative and significant effect on ROA. The results show that CAR has no significant effect on ROA, where CAR is an indicator of a bank's ability to cover a decline in its assets due to bank losses caused by risky assets. This CAR is based on the principle that every investment that contains risk must be provided with an amount of capital equal to the percentage of the total investment - the greater the ratio, the better the capital position. Under the standards set by the Bank of International Settlement (BIS), all banks in Indonesia are required to provide a minimum capital of $8 \%$ of risk-weighted assets, as explained by Kuncoro \& Suhardjono. CAR does not affect ROA. It is because Islamic banks that operate do not optimize the existing capital. The results of this study are supported by Harun ${ }^{26}$, who shows that CAR does not affect ROA.

\section{The Effect of FDR, NPF, and CAR on ROA in Islamic Commercial Banks}

The results showed that the variables FDR, NPF, and CAR together affected ROA. Based on the simultaneous test (f test) obtained Fount value of $4.628>$ from Ftable $=2.934$. Then FDR, NPF, and CAR together affect the ROA. Thus, the hypothesis used is rejected. $\mathrm{H}$ o models gained significant regression obtained a significance value of $0.009<0.055$ so that FDR, NPF, and CAR together affect the Return On Asset (ROA) variable.

\section{The Effect of FDR on ROA through CAR as an Intervening Variable in Islamic Commercial Banks}

CAR cannot mediate between FDR and Return On Assets (ROA). It is proven that the indirect effect is smaller than the direct effect. It is indicated by the multiplication value of the FDR regression coefficient on ROA (-0.365) with the CAR on Return On Assets (ROA) (0.206) which is -0.075 smaller than the FDR regression coefficient on Return On Assets (ROA) (-0.365). It can be seen that this study has no significant effect on FDR on CAR, and in fact, FDR on Return On Assets (ROA) directly has a significant effect.

\section{The Effect of NPF on ROA through CAR as an Intervening Variable in Islamic Commercial Banks}


CAR cannot mediate between NPF and Return On Assets (ROA). It is proven that the indirect effect is smaller than the direct effect. It is indicated by the multiplication value of the NPF regression coefficient on CAR (- 0.312) with the CAR on Return On Assets (ROA) (0.206) which is (-0.064) smaller than the Non-Performing Financing (NPF) regression coefficient on Return On Assets (ROA). ) (-0.312). It can be seen that this study has no significant effect between NPF on Return On Assets (ROA) through CAR, and in fact, NPF on Return On Assets (ROA) directly has a significant effect.

\section{CONCLUSION}

1. The results show that the variables Financing to Deposits Ratio (FDR) has no significant effect on the Capital Adequacy Ratio (CAR) in Islamic Commercial Banks. It is evidenced by the statistical results of the t-test, which states the significance value $(\mathrm{sig})$ of FDR is 0.063 with $=0.05$. Because the value of sig $>$ then accepts H01, there is no significant effect of FDR on CAR at Islamic Commercial Banks in 2012-2019.

2. The results showed that the Non-Performing Financing (NPF) variable had no significant effect on the Capital Adequacy Ratio (CAR). It is evidenced by the statistical results of the t-test, which states the significance value (sig) of the $\mathrm{NPF}$ is 0.109 with $=0.05$. Because the value of sig $>$ then accepts H02, there is no significant effect of NPF on CAR at Islamic Commercial Banks in 20122019.

3. The results show that the variables of Financing to Deposits Ratio (FDR) and Non-Performing Financing (NPF) together have no significant effect on the Capital Adequacy Ratio (CAR) of Islamic Commercial Banks. It is evidenced by the results of the $\mathrm{F}$ (simultaneous) test, which states that the magnitude of Fount $=2.316$ and the magnitude of Fable $=3.316$ so that all independent variables in the research model together do not affect the Capital Adequacy Ratio (CAR) in Islamic commercial banks in 2012-2019. 93

4. The results show that the variable Financing to Deposit Ratio (FDR) has no significant effect on Return On Assets (ROA) in Islamic Commercial Banks. It is evidenced by the statistical results of the t-test, which states that the significance value (sig) of FDR is 0.557 with $=0.05$. Because sig $>$ then accepts 
Ho4, FDR has no significant effect on ROA at Islamic Commercial Banks in 2012-2019.

5. The results showed that the Non-Performing Financing (NPF) variable significantly affected Return On Assets (ROA) at Islamic Commercial Banks. It is evidenced by the statistical results of the t-test, which states that the significance value ( $\mathrm{sig}$ ) of the NPF is 0.006 with $=0.05$. Because sig $<$ then accepts Ha5, there is a significant effect of NPF on ROA at Islamic Commercial Banks in 2012-2019.

6. The results show that the Capital Adequacy Ratio (CAR) variable does not significantly affect Return On Assets (ROA) at Islamic Commercial Banks. It is evidenced by the statistical results of the t-test, which states that the significance value (sig) of the CAR is 0.227 with $=0.05$. Because sig $>$ then accepts H06, CAR has no significant effect on ROA at Islamic Commercial Banks in 20122019.

7. The results show that the variables of Financing to Deposit Ratio (FDR), NonPerforming Financing (NPF), and Capital Adequacy Ratio (CAR) together have a significant effect on Return On Assets (ROA) in Islamic Commercial Banks. It is evidenced by the statistical results of the t-test, which states that the significance value ( $\mathrm{sig}$ ) of the NPF is 0.006 with $=0.05$. Because sig < then accepts $\mathrm{Ha} 7$, which means that together there is a significant influence between FDR, NPF, and CAR on ROA at Islamic Commercial Banks in 2012-2019. 94

8. The results showed that the variable Capital Adequacy Ratio (CAR) could not mediate the effect of Financing to Deposit Ratio (FDR) on Return On Assets (ROA) in Islamic Commercial Banks. It is evidenced by the results of the path analysis test, which states that the direct effect of $\mathrm{X} 1$ on $\mathrm{Y}(-0.365)$ is greater than the indirect effect of $\mathrm{X} 1$ on $\mathrm{Y}$ through $\mathrm{Z}$ (-0.075). So the intervening variable, Capital Adequacy Ratio (CAR), cannot mediate the effect of Financing to Deposit Ratio (FDR) on Return On Assets (ROA) in Islamic Commercial Banks in 2012-2019.

9. The results showed that the variable Capital Adequacy Ratio (CAR) could not mediate the effect of Non-Performing Financing (NPF) on Return On Assets (ROA) in Islamic Commercial Banks. It is evidenced by the results of the path analysis test, which states that the direct effect of $\mathrm{X} 2$ on $\mathrm{Y}(-0.312)$ is greater 
than the indirect effect of $\mathrm{X} 1$ on $\mathrm{Y}$ through $\mathrm{Z}(-0.064)$. Then the intervening variable, Capital Adequacy Ratio (CAR), cannot mediate the effect of NonPerforming Financing (NPF) on Return On Assets (ROA) in Islamic Commercial Banks in 2012-2019

\section{REFERENCE}

Hartati, S., Sudewi, P.S., dan Badren, Y. "Analisis Pengaruh CAR, BOPO, NPF dan FDR Terhadap Profitabilitas Bank BRI Syariah Cabang Cilacap. Sekolah Tinggi Ilmu Ekonomi Satria Purwokerto. 2017.

Ismail. (2016). Perbankan Syariah. Jakarta: Prenadamedia Group.

Maulida, S.N. "Pengaruh CAR, FDR, DAN BOPO TERHADAP ROA BANK UMUM SYARIAH (Studi Kasus Pada Bank Umum Syariah di Indonesia". Skripsi. IAIN Syekh Nurjati Cirebon. 2015.

Rahmah, A.R. "Analisis Pengaruh CAR, FDR, NPF, dan BOPO Terhadap Profitabilitas (Return On Assets) Pada Bank Syariah Mandiri Tahun 2013- 2017”, Skripsi. IAIN Purwokerto, 2018.

Sari, R. "Pengaruh Rasio CAR dan BOPO Terhadap Profitabilitas (ROA) Pada Bank Pembiayaan Rakyat Syariah”. Skripsi. UIN Sumatra Utara Medan. 2020.

Sriwahyuni, L. "Pengaruh Biaya Operasional dan Pendapatan Oprasional (BOPO), Financing To Deposit Ratio (FDR) dan Non Performing Financing (NPF) Terhadap Return On Asset (ROA) Pada BANK BRI SYARIAH,”. Skripsi. Ponorogo. IAIN Ponorogo. 2020.

Sugiono. (2018). Metode Penelitian Kuantitatif. Bandung: Alfabeta.

Syamsuddin, L. (1998). Manajemen Keuangan Perusahaan: Konsep Aplikasinya dalam perencanaan, pengawasan dan pengambilan keputusan. Jakarta: PT Raja Grafindo Persada.

Umam, K. (2013). Manajemen Perbankan Syariah. Bandung: CV. Pustaka.

http://www.bankvictoriasyariah.co.id, (diakses pada 1 Desember 2020, pukul 12.40). http://www.brisyariah.co.id, (diakses pada tanggal 1 Desember 2020, pukul 12.50). http://www.bankmuamalat.co.id, (diakses pada 1 Desember 2020, pukul 12.52). http://www.paninbanksyariah.co.id, (diakses pada 1 Desember 2020, pukul 13.15). www.bi.go.id Peraturan Bank Indonesia No. 17/11/PBI/2015 Www.Ojk.go.id 